\title{
Analysis of the NMDA in Focal Cerebral Ischemia in Rats
}

\author{
Análisis del NMDA en Isquemia Cerebral Focal en Ratas
}

${ }^{* *}$ Tirapelli, D. P. C.; ** Carlotti Jr, C. G.; ${ }^{* * *}$ Leite, J. P.; "Lizarte, F. S. N.; ${ }^{* *}$ Tirapelli, L. F. \& ${ }^{* *}$ Colli, B. O.

TIRAPELLI, D. P. C.; CARLOTTI JR, C. G.; LEITE, J. P.; LIZARTE, F. S. N.; TIRAPELLI, L. F. \& COLLI, B. O. Analysis of the NMDA in focal cerebral ischemia in rats. Int. J. Morphol., 30(3):979-985, 2012.

SUMMARY: NMDAR (N-methyl-D-aspartate receptor) is one subtype of ionotrophic glutamate receptor which is extensively distributed in the central nervous system (CNS). In the mammalian CNS, NMDAR serves prominent roles in the pathophysiologic process of cerebral ischemia. This study aimed to investigate the pattern of expression of protein and gene of the excitatory neurotransmitter NMDAR in experimental focal cerebral ischemia and the hole of neuroprotection with hypothermia and ketoprofen. 120 rats were randomly divided into 6 groups (20 animals each): control - no surgery; sham - simulation of surgery; ischemic - focal ischemia for 1 hour, without reperfusion; ischemic + intraischemic hypothermia; ischemic + previous intravenous ketoprofen, and ischemic + hypothermia and ketoprofen. Ten animals from each experimental group were used to establish the volume of infarct. Transient focal cerebral ischemia was obtained in rats by occlusion of the middle cerebral artery with an intraluminal suture. The infarct volume was measured using morphometric analysis of infarct areas defined by triphenyl tetrazolium chloride and the patterns of expression of the protein and gene NMDA were evaluated by immunohistochemistry and quantitative real-time PCR, respectively. Increases in the protein and gene NMDA receptor in the ischemics areas were observed and these increases were reduced by hypothermia and ketoprofen. The increase in the NMDA receptor protein and gene expression observed in the ischemic animals was reduced by neuroprotection (hypothermia and ketoprofen). The NMDA receptor increases in the ischemic area suggests that the NMDA mediated neuroexcitotoxicity plays an important role in cell death and that the neuroprotective effect of both, hypothermia and ketoprofen is directly involved with the NMDA.

KEY WORDS: NMDA expression; Cerebral ischemia; Neuroprotection (hypothermia and ketoprofen).

\section{INTRODUCTION}

The ischemic process and reperfusion trigger different pathophysiological events, among them reduced adenosine triphosphate production, loss of ion pump homeostasis, increased intracellular calcium, formation of free radicals, inflammatory response, leukocyte activation, membrane depolarization with an excessive release of excitatory amino acids such as glutamate and dopamine, and induction of apoptosis (Hachimini-Idrissi et al., 2004).

N-methyl-D-aspartate (NMDA) receptors is a type of ionotrophic $\mathrm{Ca}^{2+}$ receptor gated channel and is extensively distributed in the central nervous system (CNS). NMDAR (NMDA receptor) subunit is coded by two gene families: NMDAR1 and NMDAR2; NMDAR1 subunit is rigueur to form the NMDAR (Luo et al., 1997). In the mammalian CNS, NMDAR serves prominent roles the pathophysiologic process of ischemia becoming over excited during cerebral ischemia to induce $\mathrm{Ca}^{2+}$ influx and exacerbate neural injury
(Monaghan et al., 1989; Collingridge \& Singer, 1990).

Glutamate is the major excitatory neurotransmitter in the brain of mammals and a key mediator of intracellular communication, plasticity, growth and differentiation. The glutamate participates in ischemic neuronal injury stimulating the receptors of the calcium channels mainly the NMDA-type, allowing exaggerated penetration of intracellular calcium, which triggers the cascade of events that culminate with the enzyme cell death (theory of toxicity excitatory) (Lipton \& Rosenberg, 1994; Pulsinelli, 1995).

Several pharmacological procedures have been used in an attempt to reduce the area involved in the ischemic process. Among them, hypothermia (Baker et al., 1995; Li et al., 2005), and anti-inflammatory drugs (Asanuma et al., 1997; Dietrich et al., 1999; Dias et al., 1999) and hypothermia in combination with anti-inflammatory drugs

\footnotetext{
* Postgraduate Student-Doctorate, Department of Surgery and Anatomy, Ribeirão Preto Faculty of Medicine, University of São Paulo (USP), SP, Brazil.

** PhD, Doctor Professor-Department of Surgery and Anatomy, Ribeirão Preto Faculty of Medicine, University of São Paulo (USP), SP, Brazil.

${ }^{* * * *} \mathrm{PhD}$, Doctor Professor- Department of Internal Medicine, Ribeirão Preto Faculty of Medicine, University of São Paulo (USP), SP, Brazil.
} 
(Dietrich et al.), has proved to be effective in providing protection after cerebral ischemia. Anti-inflammatory agents are used to attenuate the inflammatory response triggered by the ischemic phenomenon (Dietrich et al.), with emphasis on ketoprofen (Asanuma et al.; Dias et al.), a non steroid agent with a very potent analgesic and anti-inflammatory action, acting as a possible antagonist of the of the NMDA receptors (McCormack et al., 1994).

One of the more intriguing reactions of cells to a severe metabolic insult is a change in their gene expression, which has become an important focus of interest in cerebral ischemia since several regulatory genes play an important role in the various aspects of infarct pathophysiology (Schneider et al., 2004). This study aimed to investigate the pattern of expression of the protein and gene NMDAR, in an experimental model of transient focal cerebral ischemia without reperfusion and the hole of neuroprotection with hypothermia and ketoprofen.

\section{MATERIAL AND METHOD}

One hundred and twenty adult male rats (Rattus norvegicus) weighing 280-310 g were used and the animals were randomly divided into 3 experimental groups: control (C), 20 animals sacrificed without being submitted to the surgical procedure; sham (S), 20 control animals submitted to complete simulation of the surgical procedure but without obstruction of the middle cerebral artery (MCA) and then sacrificed, and ischemic (I), 80 animals submitted to focal ischemia by occlusion of the MCA for 1 hour and then sacrificed. This group was subdivided into 4 subgroups of 20 animals each: ischemic subgroup ( $\mathrm{Sg} \mathrm{I}$ ), ischemic subgroup submitted to hypothermia $(\mathrm{Sg} \mathrm{IH})$, ischemic subgroup treated with ketoprofen ( $\mathrm{Sg} \mathrm{IK}$ ), and ischemic subgroup submitted to hypothermia and treated with ketoprofen (Sg IHK). Ten animals from each experimental group, for a total of 60 animals, were used for the delimitation of the ischemic area using a morphometric method, for controlling the efficacy and the extension of the ischemia.

The experiments were carried out according to the Ethical Principles for Experimental Animals (COBAO) and the study was approved by the Animal Experimentation Committee (CETEA) of the Faculty of Medicine of Ribeirão Preto, University of São Paulo (Protocol n n 0347/2005).

Induction of Cerebral Ischemia. All animals were partially anesthetized by halothane inhalation and intubated with an orotracheal cannula. At two times during the ischemic period, arterial blood samples were collected for the determination of glycemia, $\mathrm{paCO}_{2}, \mathrm{paO}_{2}$ and $\mathrm{pH}$. The animals in the $\mathrm{Sg} \mathrm{IH}$ subgroup were submitted to moderate intra-ischemic hypothermia $\left(32-34^{\circ} \mathrm{C}\right)$ by anesthesia itself and by air conditioning the room, the animals in the Sg IK subgroup received an intravenous injection of ketoprofen at the dose of $10 \mathrm{mg} / \mathrm{kg}$ body weight 5 minutes before the induction of ischemia, and the animals in the Sg IHK subgroup were submitted to intra-ischemic hypothermia and similarly injected with ketoprofen. MCA occlusion was carried out through the external carotid artery which was ligated cranially and sectioned for the retrograde introduction of a $2.5 \mathrm{~cm}$ long obstructive 4-0 mononylon suture with one end thickened with silicone over an extension of $5 \mathrm{~mm}$ (Carlotti et al., 2001). The suture was introduced until to reach the common carotid artery and then cranially progressed through the internal carotid artery until to reach and to obstruct the MCA.

Morphometric analysis of infarct volume. Infarct volumes were measured by morphometric analysis of infarct areas that were defined by 2,3,5-triphenyl tetrazolium (TTC). The brains of the animals were removed and cut into coronal sections using a rat brain matrice and were placed in a $2 \%$ solution of the dye TTC, developed at $37^{\circ} \mathrm{C}$ for 30 minutes, and then stored in $10 \%$ buffered formalin solution. Crosssectional area of the TTC-stained region for each brain slice was determined using an image analyzer (Axion vision 4.6 - Carl Zeiss). After integration of these stained areas, the indirect method of Swanson et al. was used to determine infarct volume (subtraction of residual left hemisphere cortical volume from the cortical volume of the intact right hemisphere) (Swanson et al., 1990).

Analysis of Protein Expression by immunohistochemistry. The samples were embedded in paraffin and coronal sections $(3 \mu \mathrm{m})$ of the brain were incubated with $3 \% \mathrm{H}_{2} \mathrm{O}_{2}$ and Pierce solution to block endogenous peroxidase and biotin, respectively. Sections were subsequently incubated with primary antibody against NMDA-R1 (1:200 dilution- ABBI250701 - Abbiotech $\left.{ }^{\circledR}\right)$ and with biotinconjugated secondary anti-rabbit antibody (1:1000; Vector Laboratories Inc., Burlingame, CA) and streptavidinconjugated peroxidase (Vecstatin Abc kit, Vector Laboratories Inc.). Color was developed by the addition of DAB (Sigma Chemical, St. Louis, MO). To evaluate the background reaction, procedures were also perfomed in sections incubated only with the secondary antibodies (indirect technique) or in the absence antibodies (direct technique). A field in an increase of 400x in the area where there was greater concentration of positive cells or marked (areas of "hot spots") was selected for the analysis of protein expression of NMDAR1 in each layer of immunohistochemical reaction. The number with positive staining 
for NMDAR1 was measured by using a camera (Axio Cam, Zeiss, Germany) and the program Axiovision 4.6 (Zeiss, Germany).

The method used for counting NMDAR positive cells graded from «+» to «++++» according to the intensity of immunoreactivity. The fields chosen in the slides were evaluated as the percentage of cells marked and graded from 0 (zero): no mark, up to $25 \%$ : $1+$ (low expression), $25 \%$ to 50\%: $2++$ (intermediate expression); $50 \%$ to $75 \%: 3+++$ (high expression) and over $75 \%$ of cells marked: $4++++$ (high expression).

RNA extraction and cDNA synthesis. After removal of the brain, the cortex of the left cerebral hemisphere was isolated and a sample measuring $7 \mathrm{~mm}$ in diameter was punched out for a biopsy centered along the MCA. The samples were placed in cryotubes and stored in liquid nitrogen at $-1960 \mathrm{C}$ until the time for RNA extraction. For this procedure, 250 $\mu l$ PBS $+750 \mu 1$ TRIZOL were added to the brain tissue samples which were then lysed in a Polytron homogenizer for about 3 minutes. Next, total RNA was extracted by the TRIZOL method (Invitrogen, Carlsbad, CA, USA) according to manufacturer instructions. Complementary DNA (cDNA) was constructed by reverse transcription using the enzyme Superscript II and the DNA obtained was amplified by realtime quantitative PCR (RQ-PCR).

Analysis of Gene Expression Patterns by RQ-PCR. For the quantitative analysis of the gene under study, NMDAR (Rn 01530859), we used the commercially available system TaqMan Assay-on-demand, which consists of oligonucleotides and probes (Applied Biosystems, Foster City, CA, USA). Reverse transcription was performed using $4 \mu \mathrm{g}$ total RNA for each sample in $40 \mathrm{~mL}$ of the total reaction mixture, with the addition of oligo $(\mathrm{dT})_{20}$ (Cat. $\mathrm{N}^{\mathrm{o}}$. 18418020, Invitrogen) and Superscript II reverse transcriptase (Cat. $\mathrm{N}^{\mathrm{o}}$. 18064-022, Invitrogen), according to manufacturer instructions. The cDNA obtained was diluted 1:10 and 2.5 $\mu \mathrm{L}$ was used for each $15 \mu \mathrm{L}$ of the RQ-PCR mixture using the TaqMan Master Mix (Applied Biosystems).

All reactions were carried out in duplicate and analyzed with the 7500 Sequence Detection System apparatus (Applied Biosystems). Data were analyzed using the ABI-7500 SDS software. The maximum standard deviation between duplicates was $10 \%$. The total RNA absorbed was normalized on the basis of the $\mathrm{Ct}$ value for the GAPDH gene (Rn_99999916). The variation of expression among samples was calculated by the $2^{-\Delta \Delta \mathrm{Ct}}$ method, with the mean delta $\mathrm{Ct}$ value for a group of 20 samples from control rats being used as a calibrator.

Statistical Analysis. The expression of the gene and protein under study showed normal distribution in the various groups. Data concerning the mean gene and protein expression in the various groups were analyzed statistically by one-way ANOVA followed by the Bonferroni post-test using the GraphPad Prism software, version 4.00 for Windows, (GraphPad Software, San Diego, CA, USA). The level of significance was set at $\mathrm{p}<0.05$ for two-tailed tests.

\section{RESULTS}

Morphometric analysis showed that the infarct area corresponding to the territory of irrigation of the MCA was clearly observed in the animals of the ischemic group (Fig. 1).

The analysis of the percentage of the volume of ischemic area in relation to the normal hemisphere among the animals of the ischemic group with neuroprotection $(\mathrm{SgIH}$, SgIK and SgIHK) revealed a smaller area of infarction in relation to animals of the isquemic subgroup $(\mathrm{SgI})(\mathrm{p}<0.0001$, one-way ANOVA, p = 0001, Bonferroni post-test (Fig. 1), and similar areas to that observed in animals of the control group.

Analysis of protein expression of NMDAR1 by immunohistochemistry (figure 3) showed that it was intermediate $(++)$ for all animals in the group SgI, with high intensity (+++) only in animal 10 and with average percentage of positive cells of $44.02 \%$; that in the group SgIK it was intermediate $(++)$ for all animals, with high intensity $(+++)$ only in animal 5 and the average percentage of positive cells of $38.23 \%$; and that in the groups $\mathrm{SgIH}$ and $\mathrm{SgIHK}$ it was intermediate $(++)$ in all animals and with average percentage of positive cells of $26.12 \%$ and 26.93 , respectively.

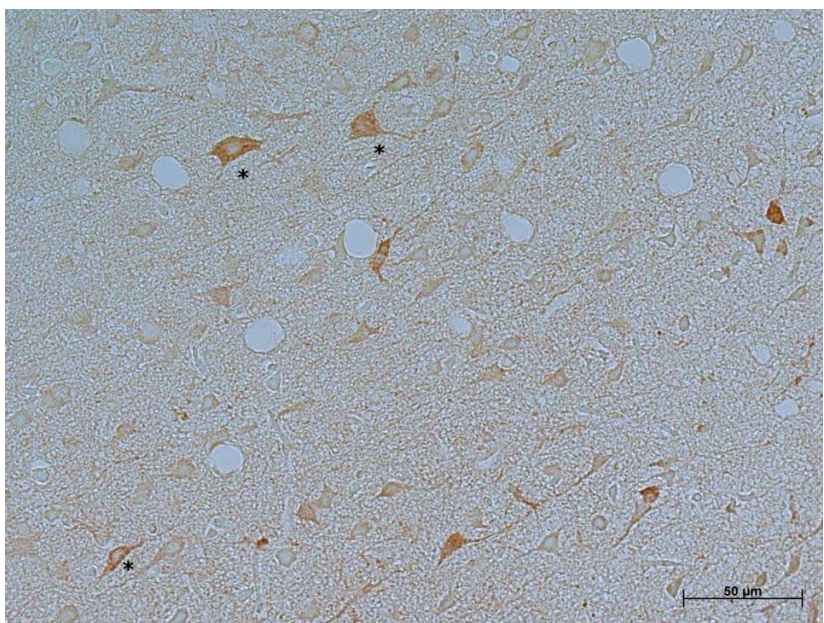

Fig. 1. Photomicrography of the expression of NMDAR1 antibody in the $\mathrm{SgIH}$ subgroup. Positive cells in the nervous tissue to the antibody (*); (400x). 
Figure 2 shows mean and standard deviation of the percentage of positive cells to NMDAR1 antibody in the ischemic group. There was a statistically significant difference $(\mathrm{p}=0.0005$ one-way ANOVA) between the subgroups $\operatorname{SgIxSgIH}(\mathrm{p}<0.001), \operatorname{SgIxSgIK}(\mathrm{p}$ $<0.05)$ and SgIxSgIHK ( $<<0.01)$, Bonferroni post test.

\section{NMDAR1}

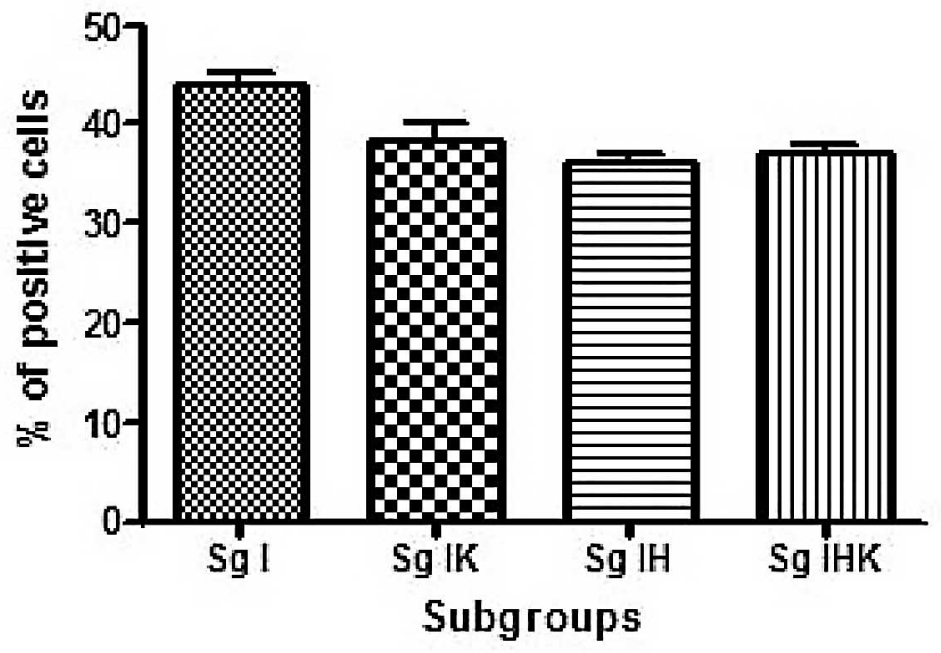

$\mathrm{Sg} I$ $\operatorname{sg} \mathrm{IK}$ $\longrightarrow \mathrm{Sg} \mathrm{IH}$ 曲 Sg IHK

Fig. 2. Mean and standard deviation of the percentage of positive cells to NMDAR1 antibody in the ischemic group.

Figure 3 illustrates the mean expression of the NMDA gene in the experimental groups. The expression in animals of the ischemic group was higher when compared with control and sham ( $\mathrm{p}=0.0001$, one-way ANOVA, $\mathrm{p}<0.05$, Bonferroni post-test $)$, and it was lower in the animals of the treated ischemic subgroups ( $\mathrm{SgIH}, \mathrm{SgIK}$ and $\mathrm{SgIHK}$ ) compared to control, sham and ischemic (SgI) animals ( $\mathrm{p}=0.0001$, one-way ANOVA, $\mathrm{p}<0.01$, Bonferroni post-test).

\section{NMDAR1}

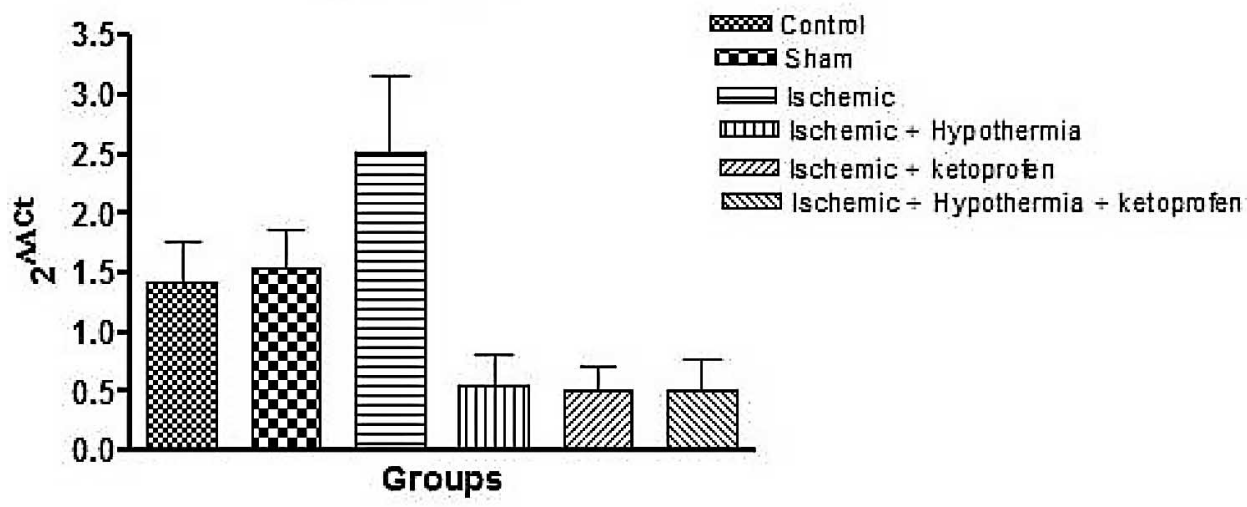

Fig. 3. Expression of the NMDAR1 gene in the groups studied. Data are reported as means \pm SD. The deviation bars indicate a $95 \%$ confidence interval.

\section{DISCUSSION}

The model of ischemia induction by occlusion of the MCA with an obstructive suture has been used by several investigators and has been shown to produce consistent and reproducible focal injuries (Dias et al.; Carlotti et al.). In our study, morphological measure of the infarct volume was randomly performed in 10 animals of each experimental group for controlling the occurrence of ischemia and confirmed the data of the literature.

$\mathrm{S}$ e $\mathrm{v}$ e $\mathrm{r}$ a 1 morphometric changes are detected in the affected cerebral area after experimental cerebral ischemia, including neuronal and glial cell death by necrosis and apoptosis (Thorburn, 2004; Matsumori et al., 2005; Siegelin et al., 2005; Zhang et al., 2006).

After minutes of a focal ischemic stroke occurring, the core of brain tissue exposed to the most dramatic blood flow reduction is fatally injured and subsequently undergoes necrotic cell death that is surrounded by a zone of less severely affected tissue but metabolically active known as "ischemic penumbra" and represents the region in which there is opportunity for salvage via poststroke therapy (Broughton et al., 2009).

The rapid depletion of energy after cerebral ischemia leads to a loss of membrane potential and 
depolarization of nerves. Voltage-dependent $\mathrm{Ca}^{2}$ channels are activated, and excitatory amino acids are released into the extracellular space (Mergenthaler et al., 2004). A cytotoxic accumulation of intracellular $\mathrm{Ca}^{2}$ subsequently occurs and is thought to initiate a series of cytoplasmic and nuclear events, including the apoptosis by intrinsic pathway (Dirnagl et al., 1999). The most studied ion channels in ischemic stroke are the group of receptor-operated cation channels opened by glutamate, which accumulates in the extracellular space during cerebral. Binding of glutamate to ionotropic NMDA and AMPA (amino-3-hydroxy-5-methyl-4-isoxazolepropionic acid) receptors promotes a further increase in $\mathrm{Ca}^{2}$ entry ischemia (Mergenthaler et al.; Simard et al., 2007).

It is well established that NMDAR is involved in the brain injury associated with acute ischemic stroke. Many studies have shown that stimulation of the neurotransmitters NMDA-type, leads to cell death in cerebral ischemia (Siciliano et al., 1996; Kumari \& Ticku, 2000; Zheng et al., 2008). It was reported that cerebral ischemia could change the expression of NMDAR subunits in the gerbil and rat brain in vivo (Kang et al., 2001; Won et al., 2001; Friedman et al., 2001). We also observed an increase in the protein and gene expression of NMDA after temporary focal cerebral ischemia in rats. This neuroexcitotoxicity observed plays an important role in apoptosis by intrinsic pathways culminating in cell death (Broughton et al.).

The large amount of glutamate accumulated in the extracellular space in the ischemic brain is probably due to glutamate release and impairment of its uptake (Rossi et al., 2000), with this high level of glutamate being thought to induce the hyperactivation of NMDARs followed by excess $\mathrm{Ca}^{2+}$ influx into neurons, and cell death (Silva et al., 2007).

Dias et al. observed histopathological differences among rats submitted to focal cerebral ischemia previously treated with ketoprofen, an antagonist of the NMDA receptor. A protective effect was also observed in the hippocampus of gerbils after a 5 minute ischemia followed by reperfusion for 21 days. Silva et al. evaluated a 48 hours period of ischemia in rats using histopathological and biochemical analyses and did not observe protective effect of ketoprofen. In the present study we observed an increase in the protein and gene expression of NMDAR1 after temporary focal cerebral ischemia and a decrease of this neurotransmitter in animals that had some kind of neuroprotection (hypothermia, ketoprofen or both), indicating a decrease in the stimulation caused by the ischemic insult.

After one hour focal cerebral ischemia in rats, NMDAR1 was highly expressed, suggesting greater NMDA receptor neurotoxicity and that the neuroprotective effect of both, hypothermia and ketoprofen is directly involved with the NMDA.

\section{ACKNOWLEDGMENTS}

This study was supported by FAPESP (Fundação de Amparo à Pesquisa do Estado de São Paulo) grant 2005/ 00381-8.

TIRAPELLI, D. P. C.; CARLOTTI JR, C. G.; LEITE, J. P.; LIZARTE, F. S. N.; TIRAPELLI, L. F. \& COLLI, B. O. Análisis del NMDA en isquemia cerebral focal en ratas. Int. J. Morphol., 30(3):979-985, 2012.

RESUMEN: NMDAR (N-metil-D-aspartato) es un tipo de receptor de glutamato ionotrópico y está ampliamente distribuido en el sistema nervioso central (SNC). En el SNC de mamíferos, NMDAR se destaca de manera importante en el proceso fisiopatológico de la isquemia cerebral. Este estudio tuvo como objetivo investigar el patrón de expresión de proteínas y genes para el NMDA neurotransmisor excitatorio experimental de la isquemia cerebral focal y el vacío en la neuroprotección con hipotermia y ketoprofeno. Se dividieron 120 ratas aleatoriamente en grupos de 6 animales cada uno (20): Control - sin cirugía; Sham - simulación de cirugía; isquémicas - isquemia focal durante 1 hora, sin reperfusión isquémica; hipotermia intra-isquémica; isquemia; previa aplicación de ketoprofeno intravenoso, e hipotermia isquémica y ketoprofeno. Diez animales de cada grupo experimental fueron utilizados para establecer el volumen de infarto. La isquemia cerebral focal transitoria fue obtenida en ratas mediante oclusión de la arteria cerebral media con una sutura intraluminal. El volumen de infarto fue medido mediante análisis morfométrico de las áreas de infarto definidas por cloruro de trifenil tetrazolio y patrones de expresión de la proteína y el gen de NMDA, fueron evaluados por inmunohistoquímica y PCR cuantitativa en tiempo real, respectivamente. Se observaron aumentos en la proteína y en el gen del receptor de NMDA en las áreas isquémicas y estos aumentos fueron reducidos por la hipotermia y ketoprofeno. El aumento de la proteína del receptor de NMDA y la expresión génica observada en los animales isquémicos fue reducido mediante hipotermia y ketoprofeno. Los aumentos del receptor de NMDA en el área isquémica sugiere que la neuro excitotoxicidad mediada por NMDA desempeña un papel importante en la muerte celular y que el efecto neuroprotector de ambos, hipotermia y ketoprofeno está directamente relacionado al NMDA.

PALABRAS CLAVE: Expresión de NMDA; Isquemia cerebral; Neuroprotección (hipotermia y ketoprofeno). 


\section{REFERENCES}

Asanuma, M.; Asanuma, S. N.; Gomez-Vargas, M.; Yamamoto, M. \& Ogawa, N. Ketoprofen, a non-steroidal antiinflammatory drug prevents the late-onset reduction of muscarinic receptors in gerbil hippocampus after transient forebrain ischemia. Neurosci. Lett., 225:109-12, 1997.

Baker, C. J.; Fiore, A. J.; Frazzini, V. I.; Choudhri, T. F.; Zubay, G. P. \& Solomon, R. A. Intraischemic hypothermia decreases the release of glutamate in the cores of permanent focal cerebral infarcts. Neurosurgery, 36: 994-1001, 1995.

Broughton, B. R. S.; Reutens, D. C. \& Sobey, C. G. Apoptotic Mechanisms After Cerebral Ischemia. Stroke, 40, 2009.

Carlotti, C. G. Jr.; Colli, B. O. \& Kazuo, J. Y. Evaluation of brain ischemia by mitochondrial respiration: experimental model. Arq. Neuropsiquiatr., 59:365-71, 2001.

Collingridge, G. L. \& Singer, W. Excitatory amino acid receptors and synaptic plasticity. Trends Pharmacol. Sci., 11:290-6, 1990.

Dias, L. A.; Colli, B. O.; Coutinho Netto, J. \& Lachat, J. J. Focal cerebral ischaemia induced by middle cerebral artery occlusion and the neuroprotective effect of ketoprofen in rats. Arq. Neuropsiquiatr., 58:1047-54. 2000.

Dietrich, W. D.; Busto, R. \& Bethea, J. R. Postischemic hypothermia and IL-10 treatment provide long-lasting neuroprotection of CA1 hippocampus following transient global ischemia in rats. Exp. Neurol., 158:444-50, 1999.

Dirnagl, U.; Iadecola, C.; Moskowitz, M. A. Pathobiology of ischaemic stroke: an integrated view. Trends Neurosci., 22: 391-7, 1999.

Friedman, L. K.; Ginsberg, M. D.; Belayev, L.; Busto, R.; Alonso, O. F.; Lin, B. \& Globus, M. Y. Intraischemic but not postischemic hypothermia prevents non-selective hippocampal downregulation of AMPA and NMDA receptor gene expression after global ischemia. Brain Res. Mol. Brain Res., 86:34-47, 2001.

Hachimi-Idrissi, S.; Van Hemelrijck, A.; Michotte, A.; Smolders, I.; Sarre, S.; Ebinger, G.; Huyghens, L. \& Michotte, Y. Postischemic mild hypothermia reduces neurotransmitter release and astroglial cell proliferation during reperfusion after asphyxial cardiac arrest in rats. Brain Res., 1019:217-25, 2004.

Matsumori, Y.; Hong, S. M.; Aoyama, K.; Fan, Y.; Kayama, T.; Sheldon, R. A.; Vexler, Z. S.; Ferriero, D. M.; Weinstein, P. R. \& Liu, J. Hsp70 overexpression sequesters AIF and reduces neonatal hypoxic/ischemic brain injury. J. Cereb. Blood Flow Metab., 25:899-910, 2005.
McCormack, K. Non-steroidal anti-inflammatory drugs and spinal nociceptive processing. Pain, 59:9-43, 1994.

Mergenthaler, P.; Dirnagl, U. \& Meisel, A. Pathophysiology of stroke: lessons from animal models. Metab. Brain Dis., 19:151-67, 2004.

Monaghan, D. T.; Bridges, R. J. \& Cotman, C. W. The excitatory amino acid receptors: their classes, pharmacology, and distinct properties in the function of the central nervous system. Annu Rev. Pharmacol. Toxicol., 29:365-402, 1989.

Kang, T. C.; Hwang, I. K.; Park, S. K.; An, S. J.; Yoon, D. K.; Moon, S. M.; Lee, Y. B.; Sohn, H. S.; Cho, S. S. \& Won, M. H. Chronological changes of N-methyl-D-aspartate receptors and excitatory amino acid carrier 1 immunoreactivities in CA1 area and subiculum after transient forebrain ischemia. J. Neurocytol., 30:945-55, 2001.

Kumari, M. \& Ticku, M. K. Regulation of NMDA receptors by ethanol. Prog. Drug Res., 54:152-89, 2000.

Li, H.; Pin, S.; Zeng, Z.; Wang, M. M.; Andreasson, K. A. \& McCullough, L. D. Sex differences in cell death. Ann. Neurol., 58: 317-21, 2005.

Lipton, S. A. \& Rosenberg, P. A. Excitatory amino acids as a final common pathway for neurologic disorders. N. Engl. J. Med., 330:613-22, 1994.

Luo, J.; Wang, Y.; Yasuda, R. P.; Dunah, A. W. \& Wolfe, B. B. The majority of n-methyl-d-aspartate receptor Complexes in adult rat cerebral cortex contain at least three different subunits (NMDAR1/NMDAR2A/NMDAR2B). Mol. Pharmacol., 51: 7986, 1997.

Pulsinelli, W. A. The therapeutic window in ischemic brain injury. Curr. Opin. Neurol., 8:3-5, 1995.

Rossi, D. J.; Oshima, T. \& Attwell, D. Glutamate release in severe brain ischemia is mainly by reversed uptake. Nature, 403: 31621, 2000.

Schneider, A.; Fischer, A.; Weber, D.; Von Ashen, O.; Scheek, S.; Kruger, C.; Rossner, M.; Klaussner, B.; $\quad$ Faucheron, N.; Kammandel, B.; Goetz, B.; Hermann, O.; Bach, A. \& Schwaninger, M. Restriction-mediated differential display (RMDD) identifies pip92 as a pro-apoptotic gene product induced during focal cerebral ischemia. J. Cereb. Blood Flow Metab., 24:224-36, 2004.

Siciliano, J. C.; Toutant, M.; Derkinderen, P.; Sasaki, T. \& Girault, J. A. Differential regulation of proline-rich tyrosine kinase 2/cell adhesion kinase beta (PYK2/CAKbeta) and pp125(FAK) by glutamate and depolarization in rat hippocampus. J. Biol. Chem., 271:28942-6, 1996. 
TIRAPELLI, D.P.C.; CARLOTTI JR, C.G.; LEITE, J.P.; LIZARTE, F.S.N.; TIRAPELLI, L.F. \& COLLI, B.O. Analysis of the NMDA in focal cerebral ischemia in rats. Int. J. Morphol., 30(3):979-985, 2012.

Siegelin, M. D.; Kossatz, L. S.; Winckler, J. \& Rami, A. Regulation of XIAP and Smac/DIABLO in the rat hippocampus following transient forebrain ischemia. Neurochem. Int., 46: 41-51, 2005.

Simard, J. M.; Tarasov, K. V. \& Gerzanich, V. Non-selective cation channels, transient receptor potential channels and ischemic stroke. Biochim. Biophys Acta., 1772:947-57, 2007.

Silva, M. N.; Colli, B. O.; Coimbra, N. C. \& Coutinho Netto, J. Evaluation of the neuroprotective effect of ketoprofen on rats submitted to permanent focal brain ischemia. Arq. Neuropsiquiatr., 65:978-84, 2007.

Swanson, R. A.; Morton, M. T.; Tsao-Wu, G.; Savalos, R. A.; Davidson, C. \& Sharp, F. R. A semiautomated method for measuring brain infarct volume. J. Cereb. Blood Flow Metab., 10:290-3, 1990.

Thorburn, A. Death receptor-induced cell killing. Cell Signal., $16: 139-44,2004$.

Won, M. H.; Kang, T.; Park, S.; Jeon, G.; Kim, Y.; Seo, J. H.; Choi, E.; Chung, M. \& Cho, S. S. The alterations of N-MethylD-aspartate receptor expressions and oxidative DNA damage in the CA1 area at the early time after ischemia-reperfusion insult. Neurosci. Lett., 301:139-42, 2001.

Zhang, Z. J.; Li, P.; Wang, Z.; Li, P. T.; Zhang, W. S.; Sun, Z. H.; Zhang, X. J. \& Wang, Y. Y. A comparative study on the individual and combined effects of baicalin and jasminoidin on focal cerebral ischemia-reperfusion injury. Brain Res., 1123: 188-95, 2006.

Zheng, Z.; Kim, J. Y.; Ma, H.; Lee, J. E. \& Yenari, M. A. Antiinflammatory effects of the $70 \mathrm{kDa}$ heat shock protein in experimental stroke. J. Cereb. Blood Flow Metab., 28:53-63, 2008.
Correspondence to:

Dr. Daniela Pretti da Cunha Tirapelli

Departamento de Cirurgia e Anatomia

Universidade de São Paulo

Faculdade de Medicina de Ribeirão Preto

Avenida Bandeirantes 3900

14049-900

Ribeirão Preto, SP

BRAZIL

Phone: +55-16-36024991

Email: daniela@fmrp.usp.br

Received: 17-11-2011

Accepted: 28-05-2012 